Diabetologia 10, 789-794 (1974)

(C) by Springer-Verlag 1974

\title{
Cationic Environment and Dynamics of Insulin Secretion III. Effect of the Absence of Potassium
}

\author{
J.C. Henquin and A.E. Lambert \\ Unité de Diabète et Croissance, University Hospital St Pierre, Louvain, Belgium \\ Received: June 10, 1974, and in revised form: August 10, 1974
}

\begin{abstract}
Summary. The absence of extracellular $\mathrm{K}^{+}$modifies glucose-induced insulin secretion. The dynamics of these changes was studied in isolated rat islets perifused with $\mathrm{K}^{+}$-deprived media containing various $\mathrm{Na}^{+}$concentrations. Omission of $\mathrm{K}^{+}$from the perifusate during stimulation with $300 \mathrm{mg}$ glucose $/ 100 \mathrm{ml}$ did not cause significant changes in IRI secretion, when $\mathrm{Na}^{+}$concentration was normal (149 $\mathrm{mM} \mathrm{Na} \mathrm{Na}^{+}$. If external $\mathrm{Na}^{+}$was partially substituted $\left(24 \mathrm{mM} \mathrm{Na} \mathrm{Na}^{+}\right.$) by choline, a decrease in the amplitude of the second phase of release was noted. Both phases were markedly depressed, when $\mathrm{Na}^{+}$was reduced to $2 \mathrm{mM}$. Removal of $\mathrm{K}+$ for 25 min before glucose stimulation resulted in an acceleration and potentiation of the early phase of release, contrasting with the progressive inhibition of the late one. This inhibition was slowly reversible $10 \mathrm{~min}$ after $\mathrm{K}^{+}$reintroduction. Under the same experimental conditions, decrease of $\mathrm{Na}^{+}$concen-
\end{abstract}

tration to $24 \mathrm{mM}$ slowed and inhibited the first phase of secretion, and depressed further the second phase, without alteration of the dynamics of secretion. Glucose oxidation by islets was reduced by $35 \%$ after $2 \mathrm{~h}$ of incubation in a $\mathrm{K}^{+}$-free medium; this inhibition was more pronounced $(65 \%)$ after $1 \mathrm{~h}$, when the islets were previously perifused for $60 \mathrm{~min}$ in the absence of $\mathrm{K}^{+}$. From these results, it is suggested that changes in glucose-induced secretion observed in the absence of $\mathrm{K}^{+}$, are secondary to the intracellular modifications of $\mathrm{Na}^{+}$and $\mathrm{K}^{+}$concentrations due to the decreased activity of the $\mathrm{Na}^{+} / \mathrm{K}^{+}$pump. They seem to be the result of two antagonistic effects: a facilitation of secretion by $\mathrm{Na}^{+}$accumulation and an inhibition by $\mathrm{K}^{+}$ depletion.

Key words: Insulin secretion, glucose oxidation, isolated islets, perifusion, glucose, potassium, sodium.
Early investigations using static incubations of rabbit pancreatic slices demonstrated that insulin secretion was stimulated, at a low glucose concentration, by removal of potassium from the extracellular medium $[1,2]$. These experiments were confirmed by studies using organ culture of fetal rat pancreas [3]. In this preparation, omission of potassium promoted insulin release in the absence of glucose and markedly potentiated the stimulant effect of glucose and/or caffeine.

On the basis of these findings, it was concluded that the accumulation of intracellular sodium, resulting from the blockade of the $\mathrm{Na}^{+} / \mathrm{K}^{+}$pump by the absence of external potassium, could make substantial contribution to the facilitation of insulin secretion [2].

The investigations reported here were aimed at characterizing further the interrelations between potassium and sodium in the regulation of insulin releasing mechanisms. This was attempted by studying the effects of potassium deprivation upon the dynamics of glucose-induced secretion from rat islets perifused with media containing normal or low sodium concentrations. Some of these results have been reported in a preliminary form [4].

\section{Material and Methods}

\section{Insulin Secretion}

Specific details for the perifusion technique of isolated islets have been described in our earlier publications $[5,6]$. Briefly, two groups of 27 islets of Langer- hans obtained from fed male rats by the collagenase method [7] were perifused in parallel, allowing control and experimental conditions to be studied simultaneously. The Krebs-Ringer bicarbonate buffer (KRB) utilized as perifusion medium was conveyed to the twin-chambers at a rate of $2.8 \mathrm{ml} / \mathrm{min}$. The effluent was collected at $30 \mathrm{~s}$ or 1 min intervals, and fractions in which immunoreactive insulin (IRI) content was to be measured were frozen until assay. KRB contained $0.5 \%$ bovine serum albumin and unless otherwise specified $50 \mathrm{mg}$ glucose $/ 100 \mathrm{ml}$. Its normal ionic composition was (in $\mathrm{mM}$ ) : $\mathrm{Na}^{+} 143.3, \mathrm{~K}^{+} 6.0, \mathrm{Ca}^{++} 2.5$, $\mathrm{Mg}^{++} 1.2, \mathrm{Cl}^{-} 126.0, \mathrm{H}_{2} \mathrm{PO}_{4}^{-} 1.2, \mathrm{SO}_{4}^{-} 1.2$ and $\mathrm{HCO}_{3}^{-}$ 24.6. $\mathrm{K}^{+}$-free media were prepared by substituting $\mathrm{KCl}$ and $\mathrm{KH}_{2} \mathrm{PO}_{4}$ by equivalent amounts of $\mathrm{NaCl}$ and $\mathrm{NaH}_{2} \mathrm{PO}_{4} . \mathrm{K}^{+}$concentration in these media was lower than $1 \mu \mathrm{M}$. In some experiments, $\mathrm{Na}^{+}$concentration was reduced to 24 or $1-2 \mathrm{mM}$ by isosmotically replacing $\mathrm{NaCl}$ alone or with $\mathrm{NaHCO}_{3}$ by corresponding choline salts. KRB was constantly gassed with a mixture of $\mathrm{O}_{2} / \mathrm{CO}_{2}(94 / 6 \%)$, so as to maintain $\mathrm{pH}$ at 7.4 during the whole experiment.

The usual experimental design started by a $25 \mathrm{~min}$ equilibration period $(\min -25$ to 0$)$, continued with a $40 \mathrm{~min}$ stimulation period $(\min 0$ to 40 ) and was terminated by a final equilibration period (min 40 to $60) . \mathrm{K}^{+}$was omitted from the medium during either the whole perifusion or the stimulation period only; except in one series of experiments, glucose concentration was increased from 50 to $300 \mathrm{mg} / 100 \mathrm{ml}$ between $\min 0$ and 40 . 
Whenever possible all chemicals were of the analytical reagent grade. D-glucose and choline chloride were purchased from Merck A.G. (Darmstadt, Germany) and choline bicarbonate from Fluka A.G. (Buchs, Switzerland). expressed as picomoles (pmol) of glucose oxidized/islet, according to Asheroft et al. [9]. In one series of experiments, large batches of islets were perifused for $1 \mathrm{~h}$ with $\mathrm{KPB}$ containing 6 or $0 \mathrm{mM} \mathrm{K} \mathrm{K}^{+}$, before incubation with labelled glucose.

Table 1. Total IRI output from perifused islets in the absence of extracellular $K^{+}$during the stimulation period

\begin{tabular}{|c|c|c|c|c|c|c|c|c|c|c|c|}
\hline \multirow{3}{*}{$\begin{array}{l}\text { Line } \\
\text { no }\end{array}$} & \multirow{3}{*}{ n } & \multicolumn{6}{|c|}{ Composition of perifusion media } & \multicolumn{3}{|c|}{ IRI released during stimulation } & \multirow{3}{*}{$P$} \\
\hline & & \multicolumn{3}{|c|}{ Equilibration } & \multicolumn{3}{|l|}{ Stimulation } & \multirow{2}{*}{$\begin{array}{l}\text { st phase } \\
\min 0.5-5.5 \\
\text { (ng/islet) }\end{array}$} & \multirow[t]{2}{*}{$P$} & \multirow{2}{*}{$\frac{\text { 2nd phase }}{\min } \frac{5.5-40}{\text { (ng/islet) }}$} & \\
\hline & & $\begin{array}{l}\text { Glucose } \\
(\mathrm{mg} / 100 \mathrm{ml})\end{array}$ & $\begin{array}{l}\mathrm{K}^{+} \\
(\mathrm{m} \mathrm{M})\end{array}$ & $\begin{array}{l}\mathrm{Na}^{+} \\
(\mathrm{mM})\end{array}$ & $\begin{array}{l}\text { Glucose } \\
(\mathrm{mg} / 100 \mathrm{ml})\end{array}$ & $\begin{array}{l}\mathrm{K}^{+} \\
(\mathrm{mM})\end{array}$ & $\begin{array}{l}\mathrm{Na}^{+} \\
(\mathrm{mVI})\end{array}$ & & & & \\
\hline $\begin{array}{l}1 \\
2\end{array}$ & 4 & $\begin{array}{l}50 \\
50\end{array}$ & $\begin{array}{l}6 \\
6\end{array}$ & $\begin{array}{l}143 \\
143\end{array}$ & $\begin{array}{l}50 \\
50\end{array}$ & $\begin{array}{l}6 \\
0\end{array}$ & $\begin{array}{l}143 \\
149\end{array}$ & $\begin{array}{l}0.00 \pm 0.02 \\
0.06 \pm 0.03\end{array}$ & NS & $\begin{array}{l}0.40 \pm 0.13 \\
0.01 \pm 0.30\end{array}$ & NS \\
\hline $\begin{array}{l}3 \\
4\end{array}$ & 6 & $\begin{array}{l}50 \\
50\end{array}$ & $\begin{array}{l}6 \\
6\end{array}$ & $\begin{array}{l}143 \\
143\end{array}$ & $\begin{array}{l}300 \\
300\end{array}$ & $\begin{array}{l}6 \\
0\end{array}$ & $\begin{array}{l}143 \\
149\end{array}$ & $\begin{array}{l}0.29 \pm 0.07 \\
0.46 \pm 0.11\end{array}$ & NS & $\begin{array}{l}7.49 \pm 1.24 \\
6.77 \pm 1.21\end{array}$ & $\mathrm{NS}$ \\
\hline $\begin{array}{l}5 \\
6\end{array}$ & 4 & $\begin{array}{l}50 \\
50\end{array}$ & $\begin{array}{l}6 \\
6\end{array}$ & $\begin{array}{r}143 \\
24\end{array}$ & $\begin{array}{l}300 \\
300\end{array}$ & $\begin{array}{l}0 \\
0\end{array}$ & $\begin{array}{r}149 \\
24\end{array}$ & $\begin{array}{l}0.71 \pm 0.13 \\
0.59 \pm 0.07\end{array}$ & NS & $\begin{array}{l}8.30 \pm 1.25 \\
5.13 \pm 0.99\end{array}$ & $<0.02$ \\
\hline $\begin{array}{l}7 \\
8\end{array}$ & 4 & $\begin{array}{l}50 \\
50\end{array}$ & $\begin{array}{l}6 \\
6\end{array}$ & $\begin{array}{r}143 \\
1\end{array}$ & $\begin{array}{l}300 \\
300\end{array}$ & $\begin{array}{l}0 \\
0\end{array}$ & $\begin{array}{r}149 \\
2\end{array}$ & $\begin{array}{l}0.63 \pm 0.10 \\
0.18 \pm 0.04\end{array}$ & $<0.02$ & $\begin{array}{l}7.61 \pm 0.56 \\
0.87 \pm 0.20\end{array}$ & $<0.001$ \\
\hline
\end{tabular}

Paired groups of islets were perifused either in the presence of $6 \mathrm{mM} \mathrm{K}+$ or in its absence, as indicated in the central part of the table; glucose and $\mathrm{Na}^{+t}$ concentrations of the perifusate are also mentioned.

Results are expressed as the mean \pm SEM of $\mathbf{n}$ experiments. Statistical significance $(P)$ refers to the comparison between the control group (1st line of each pair) and the experimental group (2nd line). NS = not significant.

IRI content of the effuent fractions was measured by a double antibody immunoassay [8] against standard solutions of rat insulin (21 IU/mg; generous gift of Dr. J. Schlichtkrull, Novo Research Institute, Copenhagen, Denmark). Results were expressed as ng IRI released/min/islet. The total amounts of IRI secreted during the first ( $\min 0.5$ to 5.5 ) and second $(\min 5.5$ to 40 ) phases of secretion in response to glucose were calculated by summation of all individual secretion rates after correction for the time of collection and subtraction of basal rate of release [5]. Negative values obtained by this mode of calculation mean that the rate of secretion continued to decline after the end of the equilibration period. Statistical significance of differences between means of experimental and control groups was assessed by Student's $t$ test for paired data.

\section{Glucose Oxidation}

Batches of 10 islets were incubated in $100 \mu \mathrm{KRB}$ (300 mg glucose $100 \mathrm{ml}, 0$ or $6 \mathrm{mM} \mathrm{K} \mathrm{K}^{+}$) supplemented with $0.2 \mu \mathrm{C}$ D-glucose-U- ${ }^{14} \mathrm{C}$ (The Radiochemical Centre, Amersham, England). The polyethylene tubes (volume:0.4 ml) containing the medium were placed inside stoppered glass tubes $(75 \times 11 \mathrm{~mm})$. After 1 or $2 \mathrm{~h}$ of incubation at $37^{\circ} \mathrm{C}$ in a shaking incubator $(140$ strokes/min), $0.6 \mathrm{ml}$ of hyamine was injected into the outer vessel and $\mathrm{CO}_{2}$ was liberated into the hyamine by injection of $50 \mu \mathrm{l}$ of $0.5 \mathrm{M} \mathrm{HCl}$ in the polyethylene tube. The incubation vials were shaken at $37^{\circ} \mathrm{C}$ for 2 further hours. Hyamine was transferred into $10 \mathrm{ml}$ of Instagel (Packard Instrument Co, Downers Grove, Illinois, U.S.A.) and the radioactivity measured by liquid scintillation spectrometry. Blank incubations were carried out for both types of medium. Results are

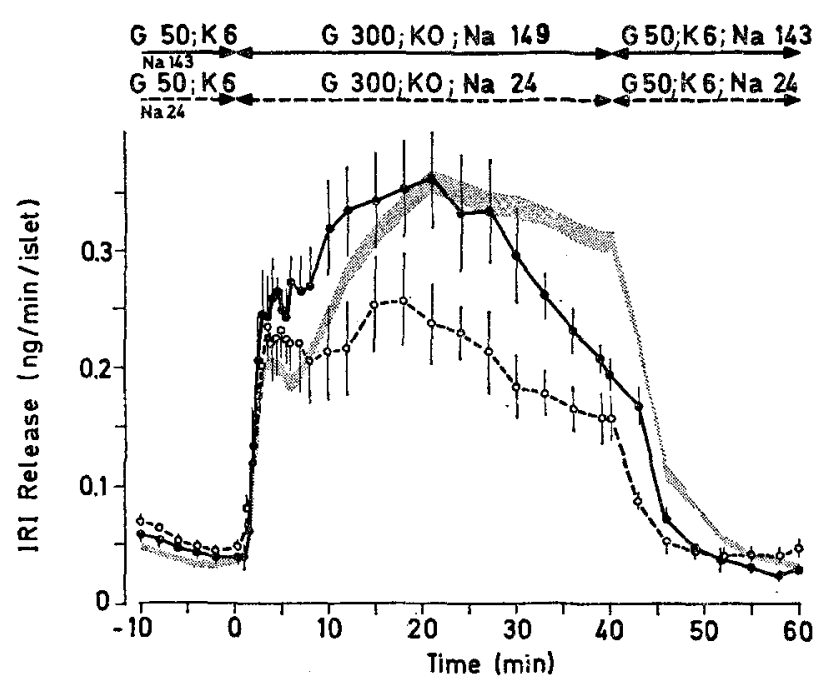

Fig. 1. Effect of the absence of extracellular potassium during the stimulation period upon IRI secretion induced by $300 \mathrm{mg}$ glucose $/ 100 \mathrm{ml}$ (G 300). Sodium concentration of the perifusate was either normal (-) or decreased to 24 mM by partial replacement by choline $(0 \cdots . . .0)$. In this and the following figures, the shaded area delimits 2 SEM of the mean IRI response to $300 \mathrm{mg}$ glucose $/ 100 \mathrm{ml}$ obtained in 75 control experiments with a medium of normal cationic composition. Only the last $10 \mathrm{~min}$ of the equilibration period are shown. Each point represents the mean \pm SEM of 4 experiments

\section{Results}

\section{Insulin Secretion}

Effect of the absence of extracellular potassium during the stimulation period. In the continuous presence of a 
low glucose concentration $(50 \mathrm{mg} / 100 \mathrm{ml})$, remoral of external $\mathrm{K}+$ from the medium, between min 0 and 40 , did not significantly augment IRI release (Table 1 , lines 1 and 2). Although some individual secretion rates were statistically elevated ${ }^{1}$ during the absence of $\mathrm{K}^{+}$, the total amount of IRI secreted was not different from that of islets maintained in normal KRB.

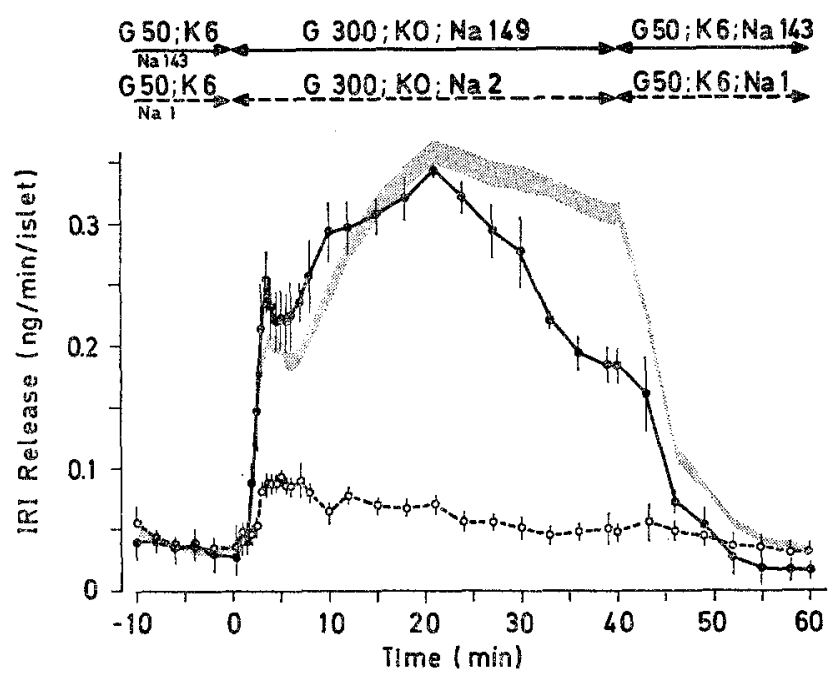

Fig. 2. Effect of the absence of extracellular potassium during the stimulation period upon IRI secretion induced by $300 \mathrm{mg}$ glucose $/ 100 \mathrm{ml}$. Perifusion medium contained either a normal sodium concentration (-) or $2 \mathrm{mM}$ sodium $(0 \ldots . .-0)$. Each point represents the mean \pm SEM of 4 experiments

When removal of $K^{+}$coincided with an elevation of glucose concentration from 50 to $300 \mathrm{mg} / 100 \mathrm{ml}$, a slight increment of the first phase and reduction of the second phase of the response to the sugar were observed. Though these modifications failed to achieve statistical significance (Table 1, lines 3 and 4), it should be noted that the secretion rates tended to decline rapidly after $25 \mathrm{~min}$ of absence of $\mathrm{K}^{+}$from the medium (Figs. 1 and 2 ; compare the solid lines with the shaded area).

When $\mathrm{Na}^{+}$had been partially substituted by choline (24 $\mathrm{mM} \mathrm{Na} \mathrm{Na}^{+}$) since the beginning of the equilibration period, the first phase of secretion in response to glucose in a $\mathrm{K}^{+}$-free medium was unaffected, but the second phase was decreased by about $40 \%$ (Fig. 1; Table 1 , lines 5 and 6 ). If $\mathrm{Na}^{+}$was omitted from the perifusion medium $(2 \mathrm{mM} \mathrm{Na})^{2}$, both phases of secretion were markedly diminished (Fig. 2; Table 1, lines 7 and 8).

Effect of the absence of extracellular potassium during the whole experiment. As shown in Fig. 3, omission of $\mathrm{K}+$ from the perifusate already during the equilibration period increased both the rapidity and the amplitude of the early secretory response to glucose stimulation

$1(p<0.05)$ on $\min 2,2.5$ and from $\min 27$ to 39 .

2 The residual $\mathrm{Na}^{+}$concentration was due to the presence of $1.2 \mathrm{mM} \mathrm{NaH} \mathrm{PO}_{4}$ in the medium and contamination by the preparation of bovine serum albumin. applied $25 \mathrm{~min}$ later $(\min 0)$. Thus individual secretion rates were significantly higher $(p<0.05)$ in the absence of $\mathrm{K}^{+}$than in its presence at min 1.5, 2.5 and 3 , and the first significant elevation of release above basal levels was noted $30 \mathrm{~s}$ earlier in the experimental group (min 1.5) than in the controls. Moreover, the amount of IRI secreted during the first $5.5 \mathrm{~min}$ of stimulation was augmented by approximately $40 \%$ (Table 2 , lines 1 and 2 ).

By contrast, such $\mathrm{K}^{+}$-deprivation not only prevented the secondary rise in secretion normally evoked by glucose, but progressively inhibited IRI release with time (Figs. 3 and 4 ; Table 2, lines 1 and 2). Increase of $\mathrm{K}^{+}$concentration from 0 to $6 \mathrm{mM}$ (min 30 ), while keeping $300 \mathrm{mg}$ glucose $/ 100 \mathrm{ml}$ did not prevent the secretion rate from declining further during the following $10 \mathrm{~min}$; thereafter the rate of secretion progressively rose to reach $0.16 \pm 0.02 \mathrm{ng} / \mathrm{min} /$ islet at the end of stimulation ( $\min 60$ ), a value not significantly lower than that of $0.21 \pm 0.02 \mathrm{ng} / \mathrm{min} /$ islet observed in the controls (Fig. 3).

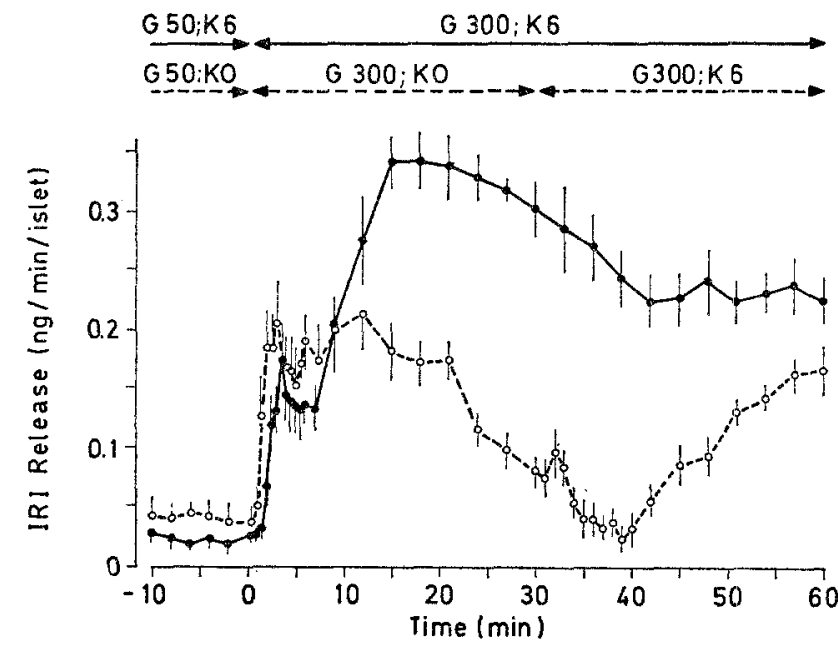

Fig. 3. Reversibility of the effect of extracellular potassium deprivation upon IRI secretion induced by $300 \mathrm{mg}$ glucose $100 \mathrm{ml}$. Potassium was absent from the perifusate betwoen min -25 and min $30(0----0)$ at which time its concentration was restored to normal. Each point represents the mean 1 SEM of 4 experiments

Decrease of $\mathrm{Na}^{+}$to $24 \mathrm{mM}$ during the whole experiment inhibited both phases of glucose-induced release observed in the absence of $\mathrm{K}^{+}$, without major alteration of the secretory pattern (Fig. 4; Table 2, lines 3 and 4). In addition, it delayed the first significant rise in secretion above baseline to $\min 3$ as compared with $\min 1.5$ in the presence of $149 \mathrm{mM} \mathrm{Na}^{+}$ (Fig. 4). In the presence of $2 \mathrm{mM} \mathrm{Na}{ }^{+}$, the two phases of secretion in response to glucose stimulation were diminished by $80 \%$ (Table 2, lines 5 and 6 ) and exhibited a dynamics similar to that of the experimental condition illustrated by Fig. 2 .

\section{Glucose Oxidation}

As shown in Table 3, the amount of glucose oxidized by the islets was not altered after $60 \mathrm{~min}$ of in- 
cubation in a $\mathrm{K}^{+}$-free medium; it was reduced by about $35 \%$ after $2 \mathrm{~h}$ in the absence of $\mathrm{K}+$. By contrast, if the islets were first perifused for 60 min with a $\mathrm{K}^{+}$deprived medium, a $65 \%$ inhibition of glucose oxidation was already evidenced at the end of the first hour of incubation.

\section{Discussion}

The validity of perifused rat islets to analyze the dynamics of IRI secretion has been established by Lacy et al. $[10,11]$ and confirmed in our previous re- sence of extracellular $K^{+}$affects the secretory response to glucose in a manner dependent on its duration and on the concentration of $\mathrm{Na}^{+}$; moreover, $\mathrm{K}^{+}$ omission can modify the two phases of release in opposite directions under some experimental conditions. Despite the rapidity of $\mathrm{K}^{*}$ withdrawal and of its reintroduction in the perifusate, the observed modifications of IRI secretion were delayed and progressive. Indeed, changes in glucose-induced secretion could not be detected until $25 \mathrm{~min}$ of $\mathrm{K}^{+}$deprivation (Figs. 1 and 2), and the inhibition of the second secretory phase was not corrected during the first $10 \mathrm{~min}$ following

Table 2. Total IRI output from perifused islets in the absence of extracellular $K^{+}$during the whole experiment

\begin{tabular}{|c|c|c|c|c|c|c|c|c|c|c|c|}
\hline \multirow{3}{*}{$\begin{array}{l}\text { Line } \\
\text { no }\end{array}$} & \multirow{3}{*}{$\mathbf{n}$} & \multicolumn{6}{|c|}{ Composition of perifusion media } & \multicolumn{3}{|c|}{ IRI released during stimulation } & \multirow{3}{*}{$P$} \\
\hline & & \multicolumn{3}{|c|}{ Equilibration } & \multicolumn{3}{|l|}{ Stimulation } & \multirow{2}{*}{$\begin{array}{l}\text { st phase } \\
\min 0.5-5.5 \\
\text { (ng/islet) }\end{array}$} & \multirow[t]{2}{*}{$P$} & \multirow{2}{*}{$\begin{array}{l}\frac{2 \mathrm{nd} \text { phase }}{\min 5.5-40} \\
\text { (ng/islet) }\end{array}$} & \\
\hline & & $\begin{array}{l}\text { Glucose } \\
(\mathrm{mg} / 100 \mathrm{ml})\end{array}$ & $\begin{array}{l}\mathrm{K}^{+} \\
(\mathrm{mM})\end{array}$ & $\begin{array}{l}\mathrm{Na}^{+} \\
(\mathrm{mM})\end{array}$ & $\begin{array}{l}\text { Glucose } \\
(\mathrm{mg} / 100 \mathrm{ml})\end{array}$ & $\begin{array}{l}\mathrm{K}^{+} \\
(\mathrm{mM})\end{array}$ & $\begin{array}{l}\mathrm{Na}^{+} \\
(\mathrm{mM})\end{array}$ & & & & \\
\hline $\begin{array}{l}1 \\
2\end{array}$ & 4 & $\begin{array}{l}50 \\
50\end{array}$ & $\begin{array}{l}6 \\
0\end{array}$ & $\begin{array}{l}143 \\
149\end{array}$ & $\begin{array}{l}300 \\
300\end{array}$ & $\begin{array}{l}6 \\
0\end{array}$ & $\begin{array}{l}143 \\
149\end{array}$ & $\begin{array}{l}0.40 \pm 0.06 \\
0.55 \pm 0.06\end{array}$ & $<0.05$ & $\begin{array}{l}8.42 \pm 0.59 \\
2.66 \pm 0.18\end{array}$ & $<0.005$ \\
\hline $\begin{array}{l}3 \\
4\end{array}$ & 4 & $\begin{array}{l}50 \\
50\end{array}$ & $\begin{array}{l}0 \\
0\end{array}$ & $\begin{array}{r}149 \\
24\end{array}$ & $\begin{array}{l}300 \\
300\end{array}$ & $\begin{array}{l}0 \\
0\end{array}$ & $\begin{array}{r}149 \\
24\end{array}$ & $\begin{array}{l}0.86 \pm 0.10 \\
0.27 \pm 0.06\end{array}$ & $<0.02$ & $\begin{array}{l}4.68 \pm 0.49 \\
1.22 \pm 0.39\end{array}$ & $<0.005$ \\
\hline $\begin{array}{l}5 \\
6\end{array}$ & 4 & $\begin{array}{l}50 \\
50\end{array}$ & $\begin{array}{l}0 \\
0\end{array}$ & $\begin{array}{r}149 \\
2\end{array}$ & $\begin{array}{l}300 \\
300\end{array}$ & $\begin{array}{l}0 \\
0\end{array}$ & $\begin{array}{r}149 \\
2\end{array}$ & $\begin{array}{l}0.76 \pm 0.05 \\
0.14 \pm 0.01\end{array}$ & $<0.001$ & $\begin{array}{l}4.87 \pm 0.34 \\
0.88 \pm 0.11\end{array}$ & $<0.001$ \\
\hline
\end{tabular}

Paired groups of islets were perifused either in the presence of $6 \mathrm{mM} \mathrm{K} \mathrm{K}^{+}$or in its absence, as indicated in the central part of the table; glucose and $\mathrm{Na}^{+}$concentrations of the perifusate are also mentioned.

Results are expressed as the mean $\perp$ SEM of $\mathbf{n}$ experiments. Statistical significance $(P)$ refers to the comparison between the control group (1st line of each pair) and the experimental group (2nd line).

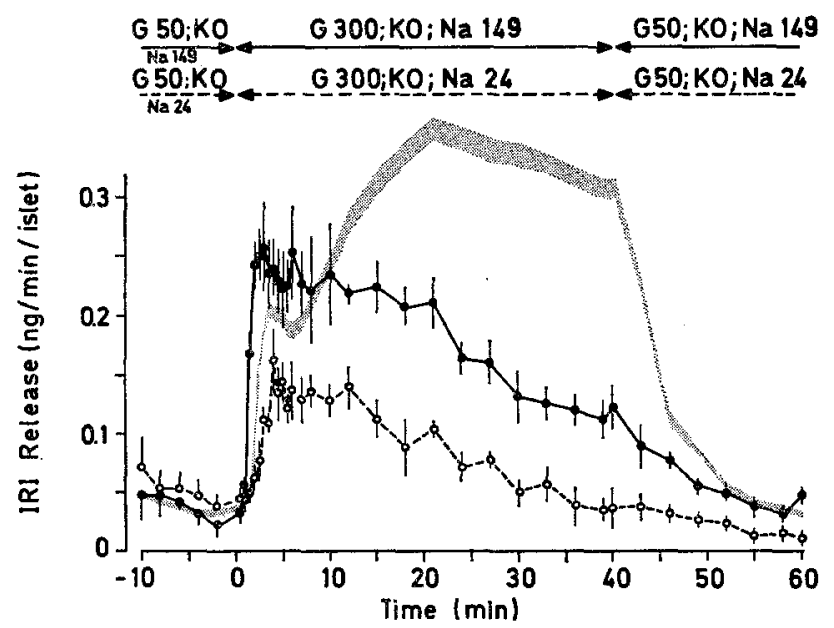

Fig. 4. Effect of the absence of extracellular potassium. during the whole experiment upon IRI secretion induced by $300 \mathrm{mg}$ glucose $/ 100 \mathrm{ml}$. Perifusion medium contained either a normal sodium concentration (-) or $24 \mathrm{mM}$ sodium $(0 \ldots . . .0)$. Each point represents the mean \pm SEM of 4 experiments

ports $[5,6,12]$. The few studies, which have been so far concerned with the effect of a $\mathrm{K}$-free medium on IRI release, reported a stimulation at both low and high glucose concentrations during incubation of adult [2] and fetal [3] pancreatic pieces.

The present experiments demonstrate that the ab- reintroduction of a normal $\mathrm{K}^{+}$concentration (Fig. 3 ). This lends support to the idea that IRI releasing mechanisms are affected by alterations of the intracellular concentrations of cations secondary to the omission of extracellular $\mathbf{K}^{+}$, rather than by the absence of $\mathbf{K}^{+}$in the medium as such. Nevertheless, restoration of the glucose effect upon correction of $\mathrm{K}^{+}$concentration indicated that the absence of the cation for $55 \mathrm{~min}$ did. not irreversibly damage the releasing function of the beta cell.

It is well known that the absence of extracellular $\mathrm{K}^{+}$decreases the activity of the membrane ATP-ase responsible for the uphill transmembraneous transport of $\mathrm{Na}^{+}$and $\mathrm{K}^{+}[13,14]$. The existence of such $\mathrm{Na}^{+} / \mathrm{K}^{+}$ pump in islet cells was suggested by studies of Howell and Taylor [15] who showed an inhibition of glucoseinduced ${ }^{42} K^{+}$uptake by ouabain. The similarity of the modifications in glucose-induced secretion that we observed in the absence of extracellular $\mathrm{K}^{+}$and in the presence of ouabain [16] suggests that these changes result from a blockade of the $\mathrm{Na}^{+} / \mathrm{K}^{+}$pump. It seems reasonable to assume that this blockade leads to a progressive accumulation of $\mathrm{Na}^{+}$and a concomitant depletion of $\mathrm{K}^{+}$in beta cells as in other cells.

The augmented intracellular $\mathrm{Na}^{+}$concentration cannot account for the progressive inhibition of the second phase of glucose-evoked secretion observed in the absence of $\mathrm{K}^{+}$. This inhibition is indeed more pronounced when the cellular accumulation of $\mathrm{Na}^{+}$is 
prevented, by decreasing to $24 \mathrm{mM}$ the concentration of the cation in the perifusate, a condition which does not affect the release in the presence of $6 \mathrm{mM} \mathrm{K} \mathrm{K}^{+}[5]$. By contrast, the diminution in intracellular $\mathrm{K}^{+}$, due to the reduced activity of the $\mathrm{Na}^{+} / \mathrm{K}^{+}$pump, may well explain our findings. Thus, this cellular $K^{+}$loss is facilitated when choline $(125 \mathrm{mM})$ partially replaces $\mathrm{Na}^{+}$in the medium $[17,18]$ and may be regarded as responsible for the increased inhibition of the second phase noted in this situation (Fig's. 1 and 4).

On the contrary, the more rapid and augmented early secretory phase of the response to glucose after 25 min of $\mathrm{K}^{+}$deprivation (Fig. 3) might be brought about by a cellular enrichment in $\mathrm{Na}^{+}[2,5]$. However, the first phase also appears to be $\mathrm{K}^{+}$-dependent. Indeed, its rate of onset and its magnitude are reduced

Table 3. Effect of potassium deprivation on glucose oxidation by isolated islets

\begin{tabular}{clcl}
\hline \multirow{2}{*}{ Time of } & \multicolumn{2}{l}{ Glucose oxidized (pmol/islet) } & $P$ \\
\cline { 2 - 4 } incubation & $6 \mathrm{mM} \mathrm{K}+$ & $0 \mathrm{mM} \mathrm{K} \mathrm{K}^{+}$ & \\
\hline $60 \mathrm{~min}$ & $22.4 \pm 1.8(6)$ & $20.5 \pm 3.1(7)$ & $\mathrm{NS}$ \\
$120 \mathrm{~min}$ & $41.2 \pm 4.8(7)$ & $26.0 \pm 3.1(7)$ & $<0.05$ \\
$60 \min ^{\mathrm{a}}$ & $18.5 \pm 1.7(12)$ & $6.4 \pm 1.3(12)$ & $<0.001$ \\
\hline
\end{tabular}

Incubations were carried out in a medium containing $300 \mathrm{mg}$ glucose $/ 100 \mathrm{ml}$ and the indicated concentration of $\mathrm{K}^{+}$.

Results are means \pm SEM of the number of determinations indicated in parentheses. Statistical significance $(P)$ refers to the comparison between the control $\left(6 \mathrm{mM} \mathrm{K} \mathrm{K}^{+}\right)$ and the experimental group $\left(0 \mathrm{mM} \mathrm{K} \mathrm{K}^{+}\right) . \mathrm{NS}=$ not significant.

a Islets perifused for $60 \mathrm{~min}$ with a medium containing 6 or $0 \mathrm{mM} \mathrm{\textrm {K } ^ { + }}$ and no glucose, before incubation.

below control values if $\mathbf{K}^{+}$has been absent and $\mathrm{Na}^{+}$ lowered to $24 \mathrm{mM}$ since the beginning of the equilibration period (Fig. 4). As the same decrease in $\mathrm{Na}^{+}$concentration does not alter the effect of glucose in the presence of $6 \mathrm{mM} \mathrm{K}+[5]$, the inhibition and the retardation of the early phase noted when the partial substitution with choline occurs in the absence of $\mathrm{K}^{+}$seem to be best explained by the facilitation of cellular $\mathrm{K}^{+}$ depletion.

There is no doubt that $\mathrm{Na}+$ plays an important role in the regulation of insulin release as underlined by the abolition of the insulinotropic effect of glucose when the cation is totally substituted by choline as well in a medium deprived of $\mathrm{K}^{+}$(Fig. 2) as in perifusates containing $6 \mathrm{mM}$ [5] or $24 \mathrm{mM} \mathrm{K}+$ [6]. However, the modulation of glucose-stimulated insulin secretion by changes in intracellular $\mathrm{Na}^{+}$appear to be dependent on the cellular $\mathrm{K}^{+}$content.

Our results showed a clear inhibition of glucose oxidation by the islets after removal of $\mathrm{K}^{+}$from the medium $^{3}$. This inhibitory effect was not detectable,

3 A similar observation was made in islets of $o b / o b$ mice by J. Sehlin and I.-B. Täljedal (personal communication) however, after $60 \mathrm{~min}$ of incubation unless the islets had been previously perifused for $1 \mathrm{~h}$ in a $\mathrm{K}+$-free medium. The more pronounced and earlier decrease in ${ }^{14} \mathrm{CO}_{2}$ production noted under this condition might be accounted for by a facilitation of cellular $\mathbf{K}^{+}$depletion in a system where the bathing medium is constantly renewed. Other experimental conditions blocking the $\mathrm{Na}+\mathrm{K}+$ pump also inhibit the metabolic activity of islets of Langerhans. Thus, ouabain has been reported to diminish both glucose oxidation [19] and glycolysis $[19,20]$. This diminution of the metabolism is indeed expected from the reduced need for energy secondary to blockade of the $\mathrm{Na}^{+} / \mathrm{K}^{+}$pump [21]. It is known however that different metabolic steps are affected by lowering $\mathrm{K}^{+}$concentration [22]; some of them might be involved in the process leading to IRI release. Such metabolic changes are in accordance with the inhibition of IRI secretion noted after $\mathrm{K}+$ removal.

In conclusion, the present data have provided new evidence that changes in intracellular $\mathrm{Na}^{+}$and $\mathrm{K}^{+}$ concentrations influence both phases of glucose-induced secretion. It is suggested that accumulation of $\mathrm{Na}^{+}$in the beta cells facilitates IRI release, but that $\mathrm{K}^{+}$ depletion depresses both phases of secretion, possibly by altering glucose metabolism. The changes in IRI release noted in the absence of extracellular $K^{+}$appear to be the result of these antagonistic actions.

Acknowledgements. This study was supported by grant 20029 from the Fonds de la Recherche Scientifique Médicale, Brussels (Belgium). J.C.H. is Aspirant of the Fonds National de la Recherche Scientifique, Brussels (Belgium). The authors are indebted to Mrs. B. DebieHoremans, Miss J. Verniers, Miss M. Nenquin and Mr. V.E. Decoster for technical assistance and to Mrs. M. Detaille for secretarial help.

\section{References}

1. Milner, R.D.G., Hales, C.N.: The sodium pump and insulin secretion. Biochim. Biophys. Acta (Amst.) 135, $375-377$ (1967)

2. Hales, C.N., Milner, R.D.G.: The role of sodium and potassium in insulin secretion from rabbit pancreas. J. Physiol. (Lond.) 194, 725-743 (1968)

3. Lambert, A.E., Jeanrenaud, B., Junod, A., Renold, A.E. : Organ culture of fetal rat pancreas. II. Insulin release induced by amino and organic acids, by hormonal peptides, by cationic alterations of the medium and by other agents. Biochim. Biophys. Acta (Amst.) 184, 540-553 (1969)

4. Henquin, J.C., Lambert, A.E.: Possible role of the sodium-pump in early and late phases of insulin release (Abstract). Europ. J. Clin. Invest. 3, 237 (1.973)

5. Lambert, A. E., Henquin, J.C., Malvaux, P.: Cationic environment and dynamics of insulin secretion. $\mathrm{I}$. Effect of low concentrations of sodium. Endocrinology 95, $1069-1077$ (1974)

6. Henquin, J.C., Lambert, A.E.: Cationic environment and dynamics of insulin secretion. II. Effect of a high concentration of potassium. Diabetes, in press.

7. Lacy, P.E., Kostianovsky, M.: Method for the isolation of intact islets of Langerhans from the rat pancreas. Diabetes 16, 35-39 (1967) 
8. Hales, C.N., Randle, P.J.: Immunoassay of insulin with insulin-antibody precipitate. Biochem. J. 88, $137-146(1963)$

9. Ashcroft, S.J.H., Weerasinghe, I.C.C., Bassett, J.M., Randle, P.J.: The pentose cycle and insulin release in mouse pancreatic islets. Biochem. J. 126, 525-532 (1972)

10. Lacy, P.E., Walker, M.M., Fink, C.J.: Perifusion of isolated rat islets in vitro. Participation of the microtubular system in the biphasic release of insulin. Diabetes 21, 987-998 (1972)

11. Lacy, P.E., Klein, N.J., Fink, C.J.: Effect of cytochalasin $B$ on the biphasic release of insulin in perifused rat islets. Endocrinology 92, 1458-1468 (1973)

12. Lambert, A.E., Henquin, J.C., Orci, L.: Role of beta cell membrane in insulin secretion. In: Proceedings of the Eighth Congress of the International Diabetes Federation, pp. 79-94 (Malaisse, W.J.,, Pirart, J., Eds). Amsterdam: Excerpta Medica 1974

13. Dunham, E.T., Glynn., I.N.: Adenosinetriphosphatase activity and the active movements of alkali metal ions. J. Physiol. (London) 156, 274-293 (1961)

14. Skou, J.C.: Enzymatic basis for active transport of $\mathrm{Na}^{+}$and $\mathrm{K}^{+}$across cell membranes. Physiol. Rev. 45, $595-617(1965)$

15. Howell, S.L., Taylor, K.W.: Potassium ions and the secretion of insulin by islets of Langerhans incubated in vitro. Biochem. J. 108, 17-24 (1968)
16. Lambert, A. E., Henquin, J.C., Malvaux, P.: Cationic environment and dynamics of insulin secretion. IV. Effect of ouabain. Horm. Metab. Res. In press.

17. Boulpaep, E.: Permeability of heart muscle to choline. Arch. Int. Physiol. Biochem. 71, 623-625 (1963)

18. Bosteels, S., Vleugels, A., Carmeliet, E.: Choline permeability in cardiac muscle cells of the cat. J. Gen. Physiol. 55, 602-619 (1970)

19. Hellman, B., Idahl, L.-A., Lernmark, A., Sehlin, J., Täljedal, I.-B.: The pancreatic $\beta$ cell recognition of insulin secretagogues. Effects of calcium and sodium on glucose metabolism and insulin release. Biochem. J. 138, 33-45 (1974)

20. Matschinsky, F.M., Ellerman, J.E.: Dissociation of the insulin releasing and the metabolic functions of hexoses in islets of Langerhans. Biochem. Biophys. Res. Comm. 50, 193-199 (1973)

21. Whittam, R., Wheeler, K.P.: Transport across cell membranes. Ann. Rev. Physiol. 32, 21-60 (1970)

22. Suelter, C.H.: Enzymes activated by monovalent cations. Science 168, $789-795(1970)$

Dr. J.-C. Henquin Hopital Universitaire St. Pierre rue de Bruxelles, 69 B-3000 Louvain Belgium 